\title{
押出成形の IT 化
}

\section{1.はじめに}

プラスチック成形加工工程における高機能, 低コストの 需要が高まる中, 押出機, 特に二軸スクリュ押出機の果た す役割は年々大きくなっている. 特に近年の多様化, 合理 化にあわせた押出機の高能力, ダウンサイジングに対する 要求は高まっており, 各社押出機メーカーはここ数年来, スクリュ回転速度の高速化と運転トルクの増加, 処理能力 の向上といったハード的性能の向上を目指してきた。しか しながら, 最近では押出機に対する市場要求は単なる生産 量重視といったハード的性能のみにとどまらず，メンテナ ンス性や技術サポートの充実などにもニーズの幅が広がっ てきている。

また，二軸スクリュ押出機での操作においては，その仕 様によってはフィーダ, 本体 (スクリュ), ギアポンプ, ダイスさらには下流装置と制御すべき機器類が多く, 装置 の立ち上げおよび運転終了時には手順に沿った操作が必要 となり, オペレータはある程度の経験を必要とする. その ため, 押出機操作に対するニーズも操作の容易性や自動化 といったソフトウェア指向が強まっており, ソフトウェア の充実性も求められるようになっている.

本稿では「押出成形の IT 化」と題し, 近年急速に進ん でいる二軸スクリュ押出機およびその周辺機器をより安全 にかつ性能を効果的に引き出すためのシステム（ソフト ウェアによるハードウェア制御）について解説を行い，二 軸スクリュ押出機に求められるトータル技術を紹介する.

\section{2. 押出機本体の制御技術}

\section{1 ネットワーク通信システム ${ }^{1), 21}$}

コンピュータによるネットワーク利用が一般的になる中， 成形加工プロセスにおいてもネットワーク技術を活用した システムが構築されている. 図 1 は生産ラインの省人化, 省力化, 高効率化を達成するため, 複数の押出機に通信機 能を搭載し，1台の PC で集中監視することが可能なシス テムである ${ }^{3}$. これは, イントラネットを介して複数台の 押出機の運転状況をくまなく把握することにより, 生産運 転の省人化, 品質管理の省力化, 生産管理の自動化を実現

\footnotetext{
* Tomiyama, Hideki

(株)日本製鋼所 広島製作所 樹脂機械部

広島市安芸区船越南 1-6-1（兵736-8602）

2003.10.14 受理
}

することが可能である．このシステムは射出成形のフィー ルドによる，多くの設備機器を集中監視するために構築さ れたシステムに起因するが，現在は小型・中型押出機が複 数台稼働する体制にある押出プロセスにおいても浸透しは じめている。このシステムはただ単に監視を行うためだけ ではなく，以下に示すような豊富な機能を搭載することで 生産ラインの集中管理が可能である.

(1)測定值データ収集機能：測定デー夕の収集と統計処理 を行い，必要なデー夕の選択表示・印刷を行う.

(2)押出成形条件管理機能：設定值条件のアップロード, ダウンロードや閲覧を行う。

(3)リモートコントロール機能 : コントローラ画面をその まま PC 上に表示可能で, 操作条件の設定・変更が PC 上で行える.

(4)アラーム送信機能：押出機の不具合発生時に指定の メールアドレスヘメッセージ送信を行う.

このネットワーク通信システムは，工場内の押出機だけ ではなく工場間の一括した運転状態の管理も可能なため, 生産体制の把握と一局集中管理が行えるメリットがある.

\section{2 コントローラの高速・高機能化}

押出機の制御を行うコントローラも昨今のコンピュータ 機器の性能向上により, CPUの 64 bit 化などへとより高 速かつ高機能化が達成されている．コントローラを高速に するメリットとしては，運転時の圧力制御モードなどで精 密なスクリュ回転あるいはギアポンプ回転の設定が可能と なり，より安定した品質確保の達成が挙げられる，機能面 では，コントローラに以下の機能を搭載することで, 経験 が浅いオペレータの補助や機械の不具合を低減することが でき，操作性・作業性の向上を可能にしている.

(1)運転アドバイス：ベントアップやフィードネックなど, 押出機の運転中に発生する様々なトラブル発生時にそ の回避方法をアドバイスする機能

(2)保守点検メッセージ : オイル交換やベアリング交換な どの正確なメンテナンス時期を事前通知することで予 防保全を実施する機能

また，コントローラの画面は従来の文字や数字だけの表 示形式であったものから, 最近ではアニメーション表示に するメーカーも増えており, 押出機の運転状態が一目で把 握しやすいようになっている（図 2).このアニメーショ ンシステムは数字による評価よりもイメージによる評価を 好む欧米で好んで採用されており，海外ユーザーの間では 


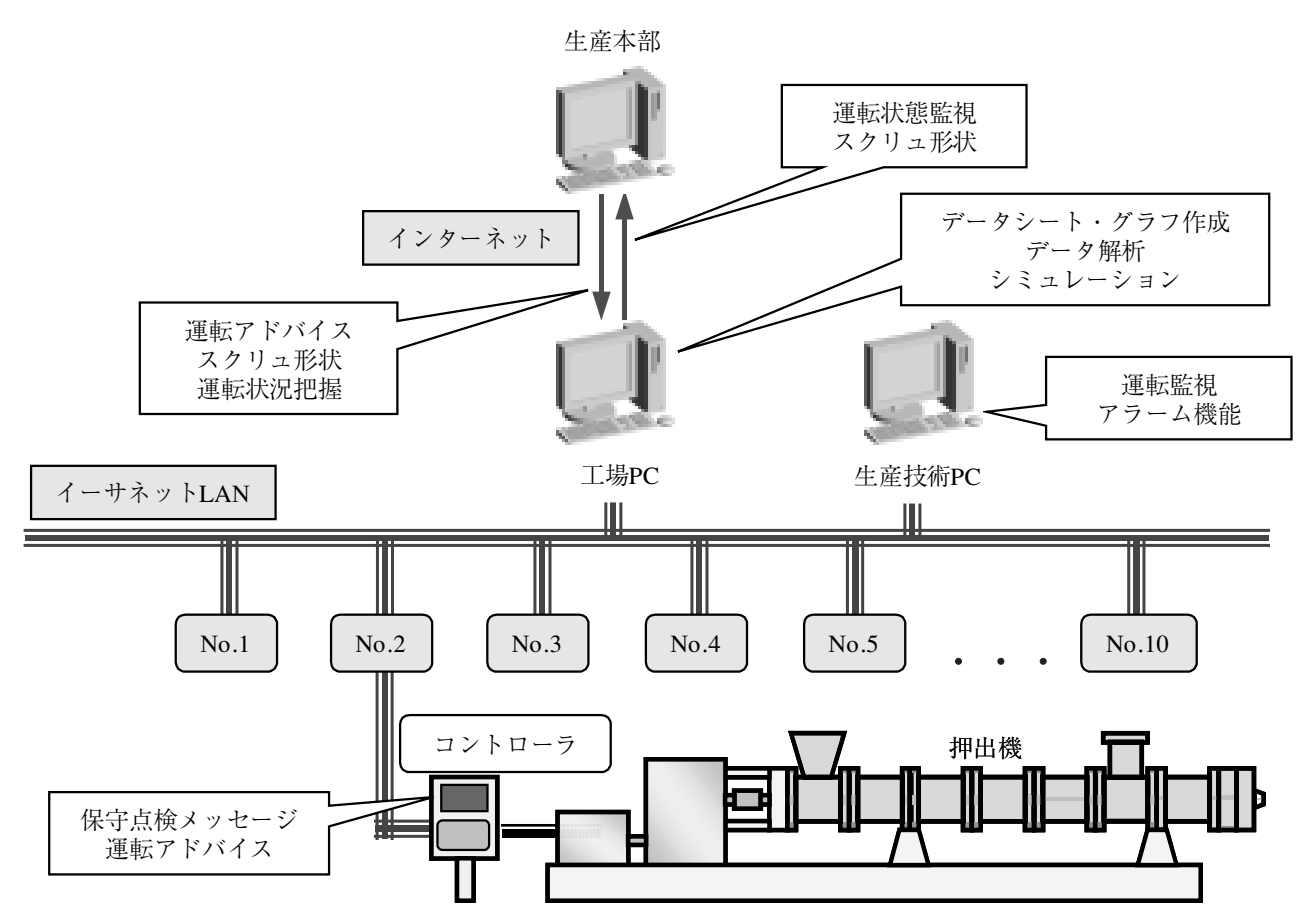

図 1 二軸スクリュ押出機の通信・制御システム

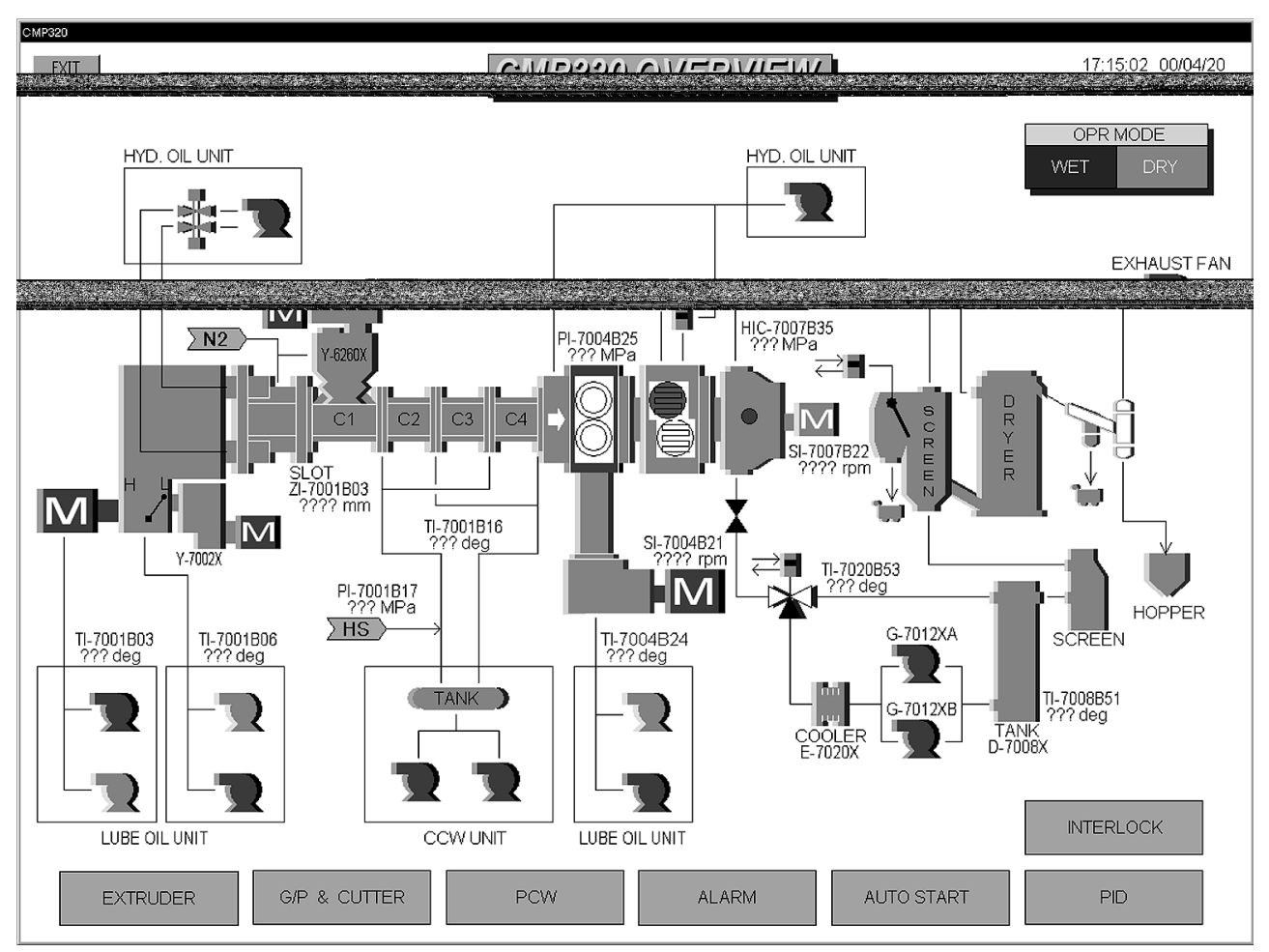

図 2 アニメーションを用いたコントロールパネル

好評を得ている.

\section{3 オートスタートシステム}

冒頭に書いたように，押出機の立ち上げ時にはオペレー 夕は各計器類の指示值を同時に監視しながら徐々に本体や 周辺機器類の設定を行い, 最終的に生産運転条件の設定を 行うという，それなりの技能が必要となる。オートスター トシステムは, 押出機の立ち上げの際, 熟練者だけでなく 経験が浅いオペレータでも安心して運転が開始できるよう に構築された制御機能である. 図 3 はフィルム成形装置に おける二軸スクリュ押出機のオートスタートシステムの概
略図である4)。このような二軸スクリユ押出機での直接成 形システムでは,

(1)押出機でコンパウンドを行うための押出機制御システム

(2)フィルム厚みの均一性を行うためのダイリップ調整シ

$$
\text { ステム }
$$

(3)フィルムを延伸，巻取りのためのロール調整システム と非常に多くの制御が必要になる. (2)(3)は目的とする製品 厚みなどによって都度調整が必要になるが，(1)関しては 樹脂原料によらずほぼ同じ手順で起動できる。オートス タートシステムはスクリュ，フィーダなどの立ち上げ手順 


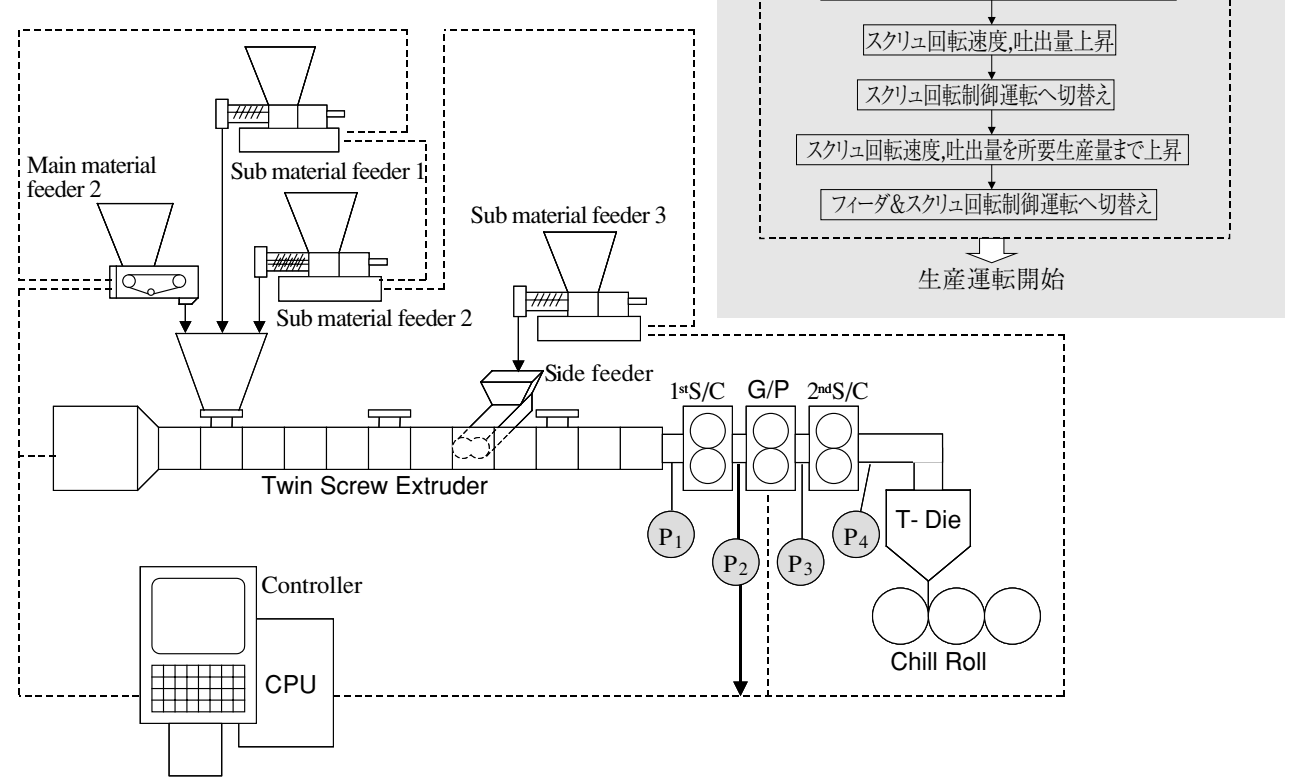

図 3 オートスタート,フィーダ集合制御システム概略図

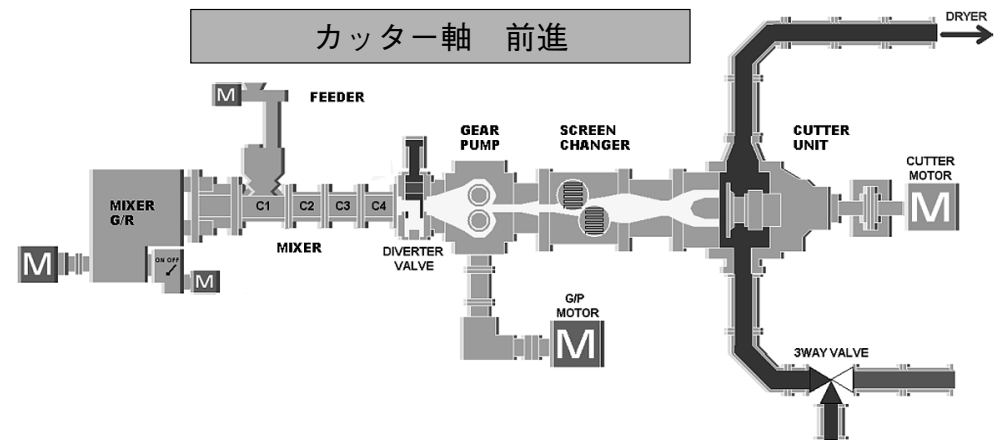

（a）立ち上げ中

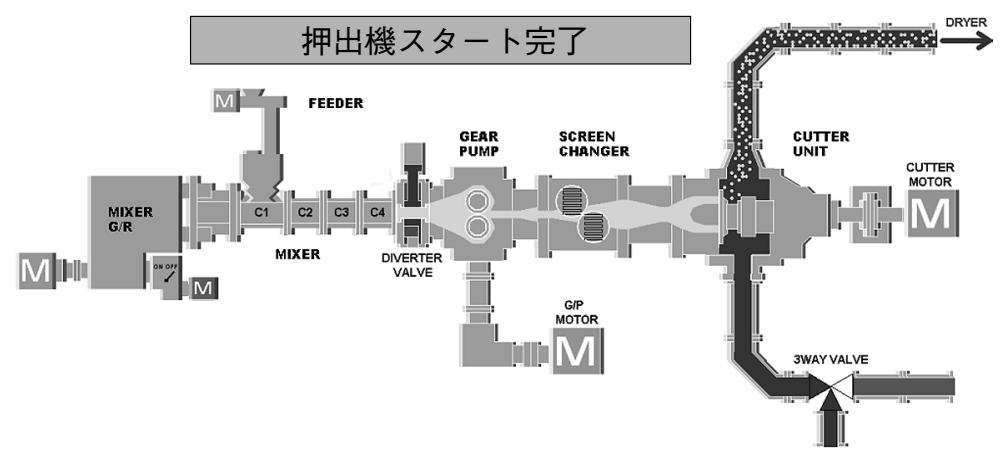

（b）立ち上げ終了（定常運転開始）

図 4 大型造粒機のオートスタートシステム

をパターン化し, 押出機に設置している各センサの応答を 見ながら順次最適な運転モードへ自動的に移行し, 最終的 に安定した生産運転が実施できるようにするものである. また,このシステムは複数の装置の制御を 1 つのコント ローラで行うため, 省スペース化にもつながる. オートス タートシステムはフィルム・シート成形装置に限らず造粒 機やコンパウンド機へも適用でき, 最近需要が膨らんでい
るリサイクル材のコンパウンドや高充填フィラー材のコン パウンドなど, 押出機の制御が困難なケースにおいても安 全な立ち上げと運転が可能となる.さらに時間あたりの処 理能力が数十トンにもおよぶ大型造粒機の場合は立ち上げ が非常に困難であるため，この制御システムは絶大な威力 を発揮する（図 4)。 


\section{3. 周辺機器の制御技術}

\section{1 フィーダ制御システム ${ }^{5)}$}

コンパウンド分野においては複数台のフィーダを用いる ことがほとんどであり, そのフィーダもホッパ内の原料の 重量を常時検知し, 供給量を自動調整する重量制御式が用 いられる. 現在では, 図 3 に示すようにこれら複数台の フィーダを押出機操作パネル上で同時に制御を行うシステ ムが確立されている. 押出機の生産運転状態においては最 終吐出量の安定化を図るため, 押出機先端の圧力を一定に 保つようにスクリュ回転数とフィーダの供給量を変動させ 制御する手法が一般的にとられるが，このフィーダの一括 制御システムを用いることで, 全体の吐出量を変化させる ために個々のフィーダの供給量を同時に変化することがで き, 常時安定した高精度供給が可能となる.また,この LAN 設備を備えた重量制御式フィーダも，最近ではリサイクル プラントや環境関連設備工事にも使用されており, ネット ワーク手法による分散制御によって, 運転操作の簡便性や 遠隔監視システムが実現されている.

\subsection{UWC 自動スタートシステム ${ }^{6)}$}

これまでのコンパウンド分野におけるペレット製造法は 主にストランドカッティング（SC）が用いられてきた. しかし，ここ最近の傾向として，アンダーウォーターカッ 卜（UWC）技術の需要が増えている。これは，SCが運転 に技術を要し, ストランド切れによる生産ロスを生じやす く常に人間による監視を必要とし, また, ペレット内に真 空泡が発生し水分・コンタミの付着が発生しやすい問題が あるのに対し, UWC は操作が容易であり, いったん生産 運転に入るとほとんど人間による監視は必要とせず，安定 したペレット製造が可能になるためである（図 5)。ただ， UWC 装置は運転開始時に押出機本体への位置合わせやオ ペレーションの最適操作が煩雑な難点がある. UWC 自動 スタートシステムは省人化, 省力化, 安易化に対するニー ズに応えるために開発された制御機構で, 以下の特徵を有 している.

(1)ボタン 1 つで自動ドッキング : スタート前の切り離し 状態から，UWC 装置の前進とロック，ダイと循環箱 の締結を自動に行う。

(2)ダイと循環箱の均一な締結：手作業での片締めによる 芯ずれを防止し，カッター刃の延命化と均一なペレッ 卜製造が可能.

流動性が良く均一な球状粒を得るることができる UWC 技術は，これまでポリオレフィンやその他沉用プラスチッ クス用途が一般的であったが, 最近では高融点エンジニア

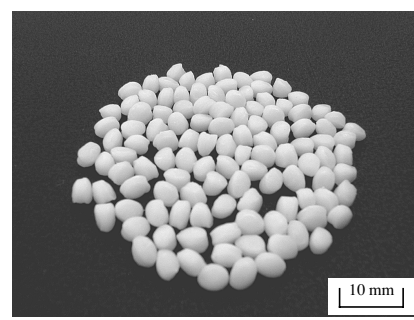

(a) UWC

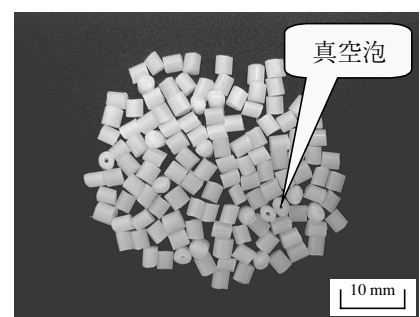

(b) SC
図 5 PA 66 のペレット形状
リングプラスチックスへの適用が求められている．そのた め, 自動スタートシステムはもとより, 熱効率の向上やぺ レット形状の改善, 大容量化といったダイスや UWC 装置 自体の性能も飛躍的に向上している.

\section{CAE によるバーチャルラボ}

CAEを用いてコンピュータ上で仮想的に成形運転を実 施し，スクリユ形状の最適化や最適押出条件の設定を見い だす手法をバーチャルラボと呼ぶ7)。これは, 以前の解析 手法の開発や解析結果の定性評価を実施していたレベルか ら, 定量的な解析・評価手法が確立されてきた最近の CAE 技術の向上によるところが大きい. バーチャルラボを実施 するには，ある程度の押出成形に関する技術とシミュレー ションに関する知識を要するが，フィラー分散や反応，脱 揮など最適な装置形状・操作条件設定が困難なコンパウン ドの要求が増える現在においては，バーチャルラボは必要 かつ重要なプロセスになりつつある.CAEによるアプロー チは以下の 2 通りの手段が考えられるが, 双方の同時取り 組みと検証実験の 3 種のデータをリンクさせなければ，ス ピートと精度が要求される現在では十分な開発が行えない と考えている，その 1 つはスクリ工構成と運転条件を変化 させたときに，押出機内の物性や混練因子分布予測をマク ロ的にシミュレーションする方法であり，スクリュ構成の 最適化と最適運転条件の設定を可能とする技術. もう 1 つ は，スクリュ個々の混練メカニズムをミクロ的にシミュ レーションする手法であり, スクリュ自体の形状変化によ る混練様式を予測し，最適なスクリュ形状を開発する技術 である. 以下に，これら 2 通りのシミュレーション技術を 実際の二軸スクリュ押出機制御へ適用する技術について述 ベる.

\section{1 スクリュ構成の最適化と最適押出条件の設定}

二軸スクリユ押出はフィーダとスクリュ回転が独立制御 であるため, 基本的に完全充満領域は混練部にしか生じず, 輸送領域においてはほとんどが非充満領域である。混練で 要求品質を満たすには, 充満領域と非充満領域をうまく作 り出し，スクリュ構成によりせん断応力による分散とひず みによる分配を使い分け，最終的に温度，圧力の制御を行 わなければならない。ただ，この充満率（滞留時間）や温 度, 圧力, 混練因子の押出機内分布はブラックボックスで あり，スクリ工交換や運転条件の特定などを試行錯誤的に 行うには多大な時間と労力を必要とする。これら試行錯誤 手段に対し, FAN（Flow Analysis Network）法を用いて， 樹脂原料・スクリ工構成・運転条件下における上記押出機 全体の混練因子分布の予測が可能な CAEソフトが活用さ れている. FAN 法による押出理論の CAE 展開は Tadmor $^{8)}, W^{2}$ te $^{9), 10)}$ らによって 30 年以上も前から実施されて いるが, The University of AKRONより販売された 「AKRO-CO-TWIN SCREW」によって世界的に活用され るようになってきた. 最近では押出メーカからもオリジナ ルソフトウェアの開発・販売が実施されており ${ }^{11)}$, ソフト ウェアによるハードウェア（二軸スクリユ押出機）の制御 手法が一般化されつつある（図 6). 現在のソフトウェア では可塑化予測やスクリュ表面の温度分布予測が可能なも のもあり, 押出機の生産能力の指標として十分な機能を備 


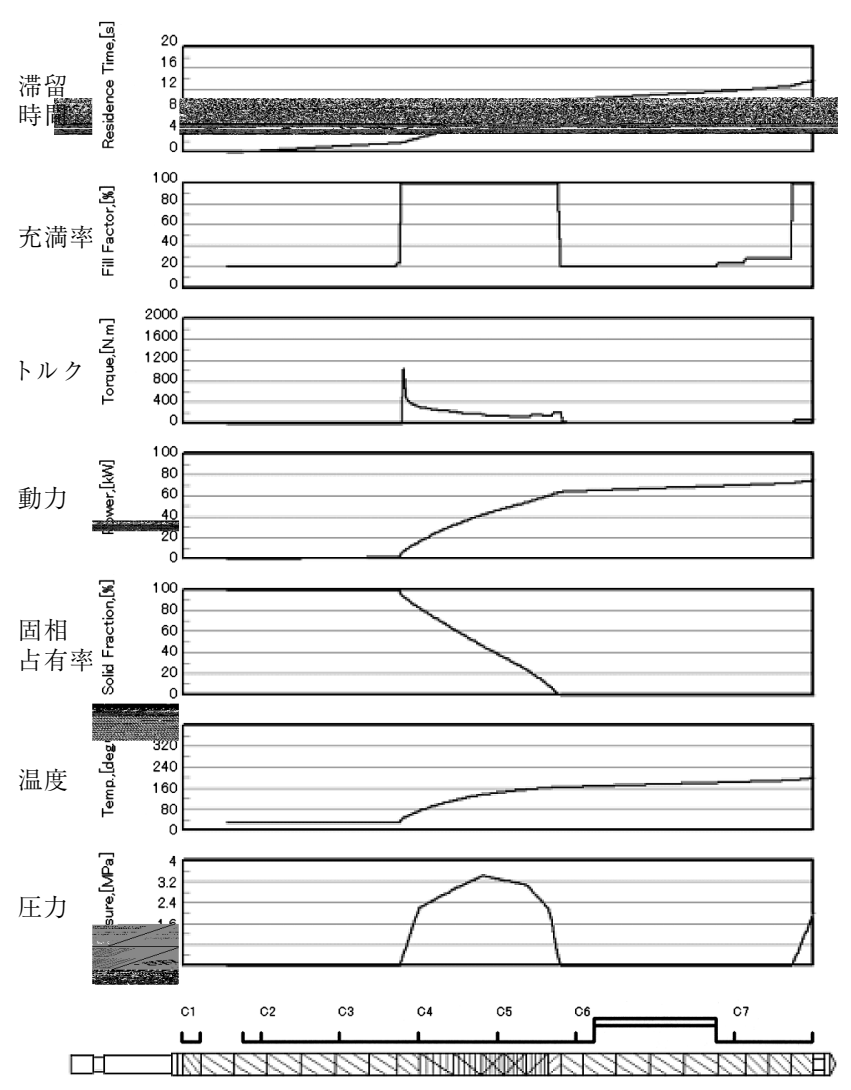

図 6 日本製鋼所「TEX-FAN」を用いたスクリュ形状と 運転条件の絞り込み解析事例

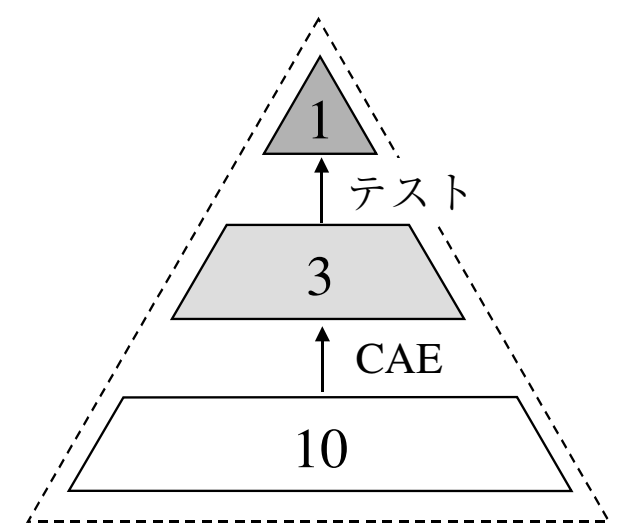

図 7 バーチャルラボによる押出条件の絞り込み

えている.

このソフトのバーチャルラボ用途としては, 主にスク リュ径が 20〜 $30 \mathrm{~mm}$ のラボ機を用いた研究開発に活用さ れている.この場合, 図 7 に示すように予め計画したスク リ工形状と運転条件を CAE で解析を実施し, いくつかの 案に絞り込む。その上でラボ機による実際のテストを実施 し，最終的に最適な条件の決定へと絞り込む手段がとられ る.この手法は押出メーカーにおいて $65 \mathrm{~mm}$ サイズ押出 機などを用いたお客様依頼テストでも実施しており, 実際 のテスト前にスクリュ形状案の絞り込みの実施や, シミュ レーション結果を用いたお客様との事前打ち合わせを $\mathrm{E}-$ mail 等で実施することで, テストの高効率化を図ってい る.また，テスト結果を基にした大型生産機へのスケール アップも, 同様のソフトウェアを用いたシミュレーション

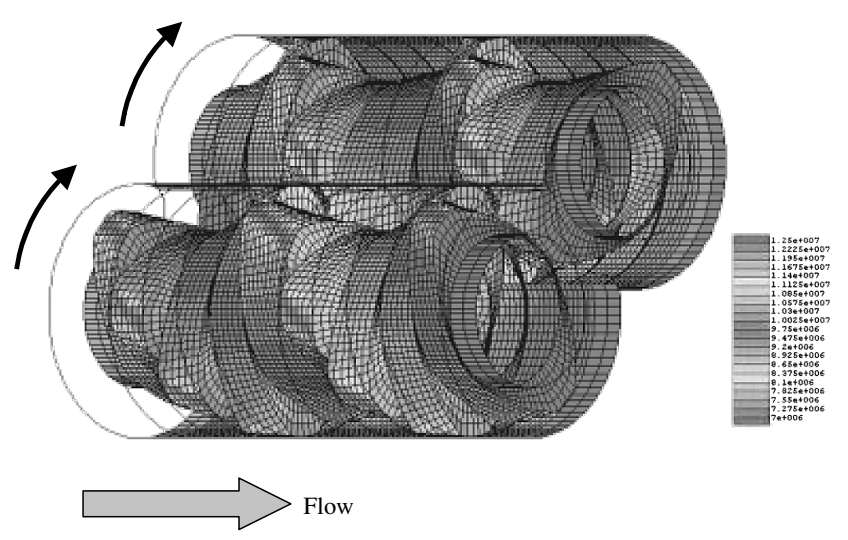

図 8 CAE を活用した新規混練スクリュの開発

を実施することで，スケールアップ手法の確実性と生産機 の信頼性向上に努めている.

\section{2 特殊スクリュ・シリンダの開発}

スクリュ個々の混練メカニズムを解明するためには，ス クリュ形状を具体的に三次元化し, FEM (有限要素法) や FVM（有限体積法）で解析を行う手法が一般的である. この手法では計算負荷の問題により押出機全体の解析は行 えないものの, 局所的な変形様式の把握による分散・分配 の発生メカニズム解明や温度, 圧力上昇機構の解明が行え, 必要な混練様式に合わせたスクリュの選択やスクリュ自体 の開発が可能である。この CAEの歴史は 10 年程度と比 較的短いが, 完全充満・完全溶融系での解析手法は既にほ ぼ確立されており ${ }^{12)}$, プラメディア社や POLYFLOW 社 などから市販品も販売されている ${ }^{13)}$.

これらソフトウェアの活用範囲は学術的な基礎理論解明 が主体となっているが，バーチャルラボによる活用も行わ れている。図 8 は CAE を活用して開発を進めた新規混練 スクリユ ${ }^{1)}$ のミュレーション事例である。このスクリュ は反応混練において局所的な反応を抑制するために開発さ れたもので, 一般的なニーディングディスクのチップ部に リードを設けた形状となっている。この開発において，従 来の試作とテストを繰り返す手法に対し, CAEを用いて ディスクのねじれ角やリードなどを変化させて傾向をつか み，試作とテストを行うバーチャルラボを実践したことで， 時間・労力・コストの抑制が達成されている.

また，このCAE 手法を用いた解析対象はスクリュだけ ではなくシリンダへも展開されている ${ }^{14)}$. 図 9 は通常のシ リンダに溝を設けた特殊混練シリンダの解析結果である. このシリンダの場合は CAEによって開発を実施したわけ ではないが, ブラックボックスのためテストでは詳細な把 握が困難だった混練メカニズムが CAEによって解明され, テストで得られていた分配性能の高さ ${ }^{15}$ が証明されたケー スである、ただ，この場合もただ単にCAEで混練メカニ ズムを証明するだけではなく, より混練性能を高めるため の溝形状の最適化解析を実施し, 解析結果による試作とテ ストの実施といったソフトウェアとハードウェアをうまく リンクさせることで, 樹脂原料やコンパウンド様式に合わ せた最適装置の適用が可能になるものと期待できる. 


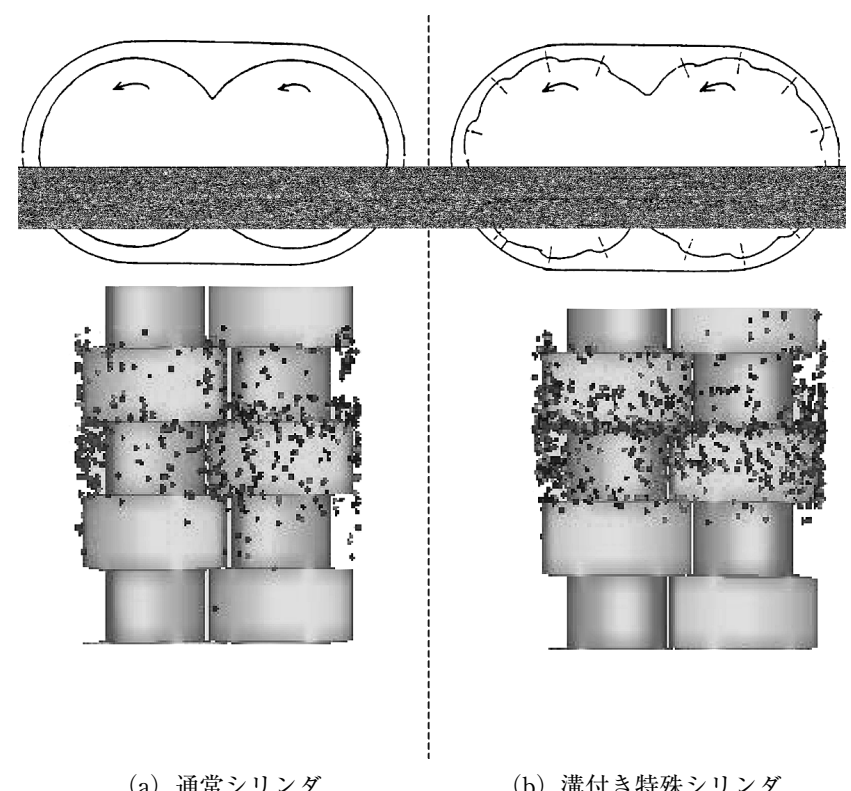

図 9 三次元解析による特殊シリンダの分配性能評価

\section{5.おわりに}

今後のプラスチックス材料の製造プロセスは，さらに合 理化の方向に向かう傾向があるため，ITを活用した二軸 スクリュ押出機の集中管理や自動運転システムなどソフト 面の充実に対する要望はさらに高まってくると予想される。 また，押出機メーカーにおいても機械を製造・納入した後 はスムーズな立ち上げが行えるよう，CAEによる十分な 事前検討や精度の高い制御システムを構築し, より信頼性 の高い製品を提供する必要がある。CAE や制御技術をは じめとするハードウェア制御のためのソフトウェアシステ ム化は今後さらに重要になってくることが予想され，その
技術発展のためにメーカーとユーザーが連携した取り組み を進めていくことが重要である.

\section{考 文 献}

1 ）井上茂樹：プラスチックスエージ，49(6)，80(2003)

2 ）井上茂樹 : 産業機械, 631 (4)，43（2003）

3 ）日本製鋼所：プラスチックスプロセッシングテクノロ ジー ニュースレター, 49

4) 日本製鋼所：プラスチックスプロセッシングテクノロ ジー ニュースレター, 60

5 ）日本製鋼所：プラスチックスプロセッシングテクノロ ジー ニュースレター, 7

6 ）日本製鋼所：プラスチックスプロセッシングテクノロ ジー ニュースレター, 29

7 ）辰巳昌典：プラスチックス，54（5），26（2003）

8 ) Tadmor, Z., Broyer, E. and Gutfinger, C. : Polym Eng. Sci., 14, 660 (1974)

9 ) White, J.L. and Szydlowski, W. : Adv. Polym. Tech., 7, 419 (1987)

10) Szydlowski, W., Brzoskowski, R. and White, J. L. : Intern. Polym. Process., 1, 207 (1987)

11）日本製鋼所：プラスチックスプロセッシングテクノロ ジー ニュースレター, 53

12) Funatsu, K., Kihara, S., Miyazaki, M., Katsuki, S. and Kajiwara, T. : Polym. Eng. Sci., 42 (4), 707 (2002)

13）吉川秀雄：プラスチックスエージ， 47 (8), $119(2001)$

14）梶原稔尚, 寺尾義範, 魚谷 晃, 辻 哲治, 富山秀樹, 船津和守：プラスチック成形加工学会 第 14 回年次 大会講演予稿集（2003）

15）小田勝広, 井上茂樹, 柿崎 淳, 新谷浩昭：成形加工, 15 (5), 342 (2003)

\section{——お詫びと訂正}

『成形加工』 2003 年 9 月号（第 15 巻，第 9 号）の $\lceil$ 明治大学理工学部機械工学科材料強度研究室の紹介」 におきまして以下の䛊りがありましたので訂正させて いただきます。

$<$ p. 617 右段下から 2 行目 $>$

(誤) 製品評価技術研究所
（正）独立行政法人製品評価技術機構

$<$ p. 618 左段上から 1 行目 $>$

(誤) NEDO

（正）経済産業省

関係各位にご迷惑をおかけしましたことをお詫び申 し上げます。 